\title{
KARAKTERISTIK DAN NILAI EKONOMI SUMBERDAYA PERAIRAN KOMPLEK DANAU TEMPE, SULAWESI SELATAN
}

\author{
Andrian Ramadhan', Riesti Triyanti' ${ }^{1}$, Sonny Koeshendrajana1
}

\begin{abstract}
ABSTRAK
Sumberdaya perairan umum daratan merupakan sumberdaya yang memiliki karakteristik unik, baik menurut tipologi, dinamika hidro-bioekologi maupun pola pemanfaatannya. Salah satu tipe yang ada adalah sumberdaya perairan Komplek Danau Tempe. Tujuan dari penelitian ini adalah untuk mengetahui karakteristik sumberdaya, jenis dan pola pemanfaatan serta nilai ekonomi sumberdaya di Komplek Danau Tempe. Penelitian ini dilakukan pada bulan Juli-Agustus 2007. Metode penelitian yang digunakan adalah metode penelitian survey. Analisis data dilakukan secara deskriptif dan kuantitatif. Hasil penelitian menunjukkan bahwa Komplek Danau Tempe terbentuk pada saat musim hujan ketika air yang berasal dari sungai-sungai disekitarnya meluap dan menggenangi sebagian wilayah daratan. Kondisi tersebut mempengaruhi cara masyarakat dalam memanfaatkan sumberdaya di Komplek Danau Tempe. Nilai ekonomi total dari pemanfaatan sumberdaya yang diperhitungkan dari kegiatan penangkapan ikan, pertanian dan transportasi umum masyarakat adalah sebesar Rp.1.489.149.383.605 Besarnya nilai tersebut mencerminkan bahwa keberadaan sumberdaya perairan danau Tempe memiliki peranan penting secara ekonomi baik bagi masyarakat maupun pemerintah.
\end{abstract}

\section{Kata kunci : Sumberdaya, Karakteristik, Danau Tempe, Nilai Ekonomi,}

\section{Abstract: Characteristics and Economic Value of Water Resource of the Tempe Lake, South Sulawesi.By Andrian Ramadhan, Riesti Triyanti and Sonny Koeshendrajana}

Inland water resources have unique characteristics, in terms of not only typological and hydrobioecological dynamic, but also utilisation pattern. One example of the resource is the Tempe lake. This research was aimed to explore resource characteristics, type and pattern of resource utilization, and its economic value. This research was conducted on July 2007. Method used in this research was a survey method. Data were analyzed descriptively and quantitatively. Result showed that Tempe Lake is being formed by rivers flew during rainy season. This, in favor affects utilization pattern of society who live surrounding the resources. Total economic value of resource utilization was Rp. 1.489 billion, consisting of fishing, agriculture and public transportation activities. This indicate that water resource of the Tempe Lake plays an important role economically for society and government.

\section{Keyword: Resource, Characteristic, Tempe Lake, Economic Value}

\section{PENDAHULUAN}

Sumberdaya perairan umum daratan menyimpan potensi ekonomi yang cukup besar untuk dimanfaatkan. Hal ini disadari sepenuhnya baik oleh pemerintah maupun masyarakat. Oleh karena itu, pada umumnya pemanfaatan pada kawasan perairan umum daratan telah dilakukan secara intensif. Begitu pula dengan sumberdaya perairan komplek Danau Tempe yang terletak di bagian utara
Propinsi Sulawesi Selatan. Sumberdaya perairan telah dimanfaatkan untuk berbagai kepentingan diantaranya adalah penangkapan sumberdaya ikan, pertanian, dan transportasi air.

Komplek Danau Tempe pada dasarnya merupakan danau banjiran yang akan membentuk suatu komplek danau pada saat curah hujan tinggi dan surut pada saat musim kering yang menyisakan tiga buah danau yaitu danau Tempe, danau Sidenreng dan danau

\footnotetext{
1 Peneliti pada Balai Besar Riset Sosial Ekonomi Kelautan dan Perikanan

JI. KS. Tubun Petamburan VI, Jakarta 10260. Telp. 021 53650162/Fax. 02153650159
} 
Buaya. Kondisi tersebut kemudian membentuk pola-pola pemanfaatan sumberdaya oleh masyarakat dalam rangka mendapatkan keuntungan secara ekonomi dari keberadaan sumberdaya.

Tujuan penelitian ini adalah untuk memberikan gambaran mengenai karakteristik dan estimasi nilai ekonomi dari pemanfataan sumberdaya yang dilakukan oleh masyarakat. Hal tersebut merupakan informasi dasar yang dibutuhkan dalam merumuskan kebijakan pengelolaan sumberdaya.

\section{METODOLOGI}

\section{Lokasi dan Waktu Penelitian}

Penelitian dilakukan pada dua kabupaten yang berbatasan langsung dengan Kompleks Danau Tempe yaitu Kabupaten Wajo dan Kabupaten Sidrap. Pemilihan lokasi didasari oleh letak kompleks Danau Tempe yang 90\% berada dalam wilayah administrasi Kabupaten Wajo dan Kabupaten Sidrap. Penelitian dilakukan antara bulan Juli sampai dengan bulan Agustus tahun 2007.

\section{Ruang Lingkup Penelitian}

Untuk melakukan penilaian terhadap pemanfaatan sumberdaya perairan danau diperlukan pemahaman terkait dengan karakteristik pemanfaatan sumberdaya. Karakteristik pemanfaatan sumberdaya akan memberikan gambaran jenis-jenis sumberdaya apa yang dapat dimanfaatkan dan bagaimana sumberdaya tersebut dimanfaatkan. Kedua hal tersebut dibutuhkan sebagai dasar untuk memahami aktivitas ekonomi dan pola pemanfaatan sumberdaya, serta. mengestimasi nilai manfaat ekonomi sumberdaya

Nilai ekonomi memberikan gambaran bahwa nilai terhadap sumberdaya tidak hanya berupa nilai pasar (market value) akan tetapi memberi nilai hubungan antara ekologi dan ekonomi secara terintegrasi (Adrianto, 2006). Constanza and Folke (1997) dalam Adrianto
(2006) menyebutkan bahwa dalam pandangan ekonomi ekologi, tujuan valuasi terhadap sumberdaya alam tidak semata terkait dengan maksimisasi kesejahteraan individu, melainkan juga terkait dengan tujuan keberlanjutan ekologi dan keadilan distribusi manfaat. Hal ini sejalan dengan yang diungkapkan oleh Dosi (2000) bahwa translasi dari preferensi individu menjadi nilai moneter direkomendasikan sebagai bentuk operasional dari langkah alternatif atas kebutuhan valuasi yang bersifat ex-ante (sebelum kegiatan/proyek dijalankan) maupun ex-post (sesudah kegiatan/ proyek dijalankan).

\section{Metode Analisis Data}

Data dianalisis secara deskriptif dan kuantitatif. Analisis data secara deskriptif digunakan untuk menjelaskan aktivitas masyarakat yang memanfaatkan sumberdaya perairan umum danau. Analisis data kuantitatif digunakan untuk menghitung nilai manfaat langsung sumberdaya danau. Pendekatan yang digunakan dalam analisis ini adalah pendekatan Effect On Production (EOP) yang mempertimbangkan aspek ekologi dan ekonomi. Perubahan pada aspek ekologi akan mempengaruhi nilai ekonomi sumberdaya. Langkah-langkah dalam pendugaan nilai ekonomi sumberdaya dijabarkan sebagai berikut (Adrianto, 2006):

- Langkah(1). Me mbangun fungsi permintaan terhadap penggunaan suatu sumberdaya

$$
Q=\beta_{0} X_{1}^{\beta 1} X_{2}^{\beta 2} \ldots X_{n}^{\beta n}
$$

- Langkah(2). Mentransformasi fungsi permintaan menjadi bentuk persamaan harga linear

$$
\begin{aligned}
& \operatorname{Ln} Q=\beta_{0}+\beta_{1} \operatorname{Ln} X_{1}+\beta_{2} \operatorname{Ln} X_{2}+\ldots \beta_{n} L_{n} X_{n} \\
& \operatorname{Ln} Q=\left(\left(\beta_{0}+\beta_{2}\left(\operatorname{Ln} X_{2}\right)+\ldots \beta_{n}\left(\operatorname{Ln} \overline{X_{n}}\right)\right)+\beta_{1} \operatorname{Ln} X_{1}\right. \\
& \operatorname{Ln} Q=\beta^{1}+\beta_{1} \operatorname{Ln} X_{1}
\end{aligned}
$$


- Langkah(3). Mentransformasi kembali fungsi permintaan menjadi bentuk persamaan as a I (Langkah 1)

$$
Q=\exp \left(\beta^{\prime}\right) X_{1}^{\beta 1} \text { atau } Q=\beta X_{1}^{\beta 1}
$$

- Langkah(4). Mentransformasi fungsi permintaan menjadi bentuk persamaan harga non-linear

$$
X_{1}^{\beta_{1}}=\frac{Q}{\beta} \text { atau } X_{1}=\frac{Q^{\frac{1}{\beta_{1}}}}{\beta^{\frac{1}{\beta_{1}}}}
$$

- Langkah(5).Mengestimas i Total Kesediaan Membayar

$$
U=\int_{0}^{a} f(Q) d Q
$$

- Langkah(6). Mengestimasi Surplus Konsumen

$$
\begin{aligned}
& C S=U-P t \\
& P t=X 1 \times \bar{Q}
\end{aligned}
$$

dimana :

$\mathrm{Q}=$ Jumlah sumberdaya yang diminta selama setahun/ Annual resources demand

$\beta \mathrm{i}=$ Koefisien regresi parsial/Partial regression coefficient

$\mathrm{X} 1=$ Harga $/$ Price

$\mathrm{X} 2=$ Umur responden/Respondent age

X3 = Pendidikan responden/ Responcent education

$\mathrm{X} 4=$ Jumlah anggota Keluarga/ Number of family member

$\mathrm{X} 5=$ Pendapatan/Revenue

$\mathrm{X} 6=$ Pengalaman usaha/Bussiness experience

$\mathrm{U}=$ Total kesediaan membayar $/$ Total ability to pay

$\mathrm{CS}=$ Surplus konsumen/Consumer surplus

$f(\mathrm{Q})=$ Fungsi harga/Price function

$\bar{Q}=$ Jumlah rata-rata sumberdaya yang diminta/Average resource demand

$\mathrm{Pt} \quad=$ Nilai yang dibayarkan/Paying value

\section{HASIL DAN PEMBAHASAN}

\section{Karakteristik Ekosistem Danau Tempe}

Danau Tempe termasuk habitat danau banjiran (plain lake) dan membentuk satu kompleks danau dengan Danau Sidendreng. Hampir seluruh hutan sekitar danau telah habis (gundul), kecuali hutan rawang antara Danau Tempe dan Sidendreng (Koeshendrajana et al, 2007). Kondisi DanauTempe banyak mengalami perubahan dari tahun ketahun bila dilihat dari luasan dan kedalamannya. Saat ini luas Danau Tempe pada saat air pasang diperkirakan dapat mencapai 28.643 ha (Putra dan Sadat, 2007). Wilayah terbesar masuk kedalam wilayah administrasi Kabupaten Wajo (54,6\%), sedangkan sisanya masuk kedalam Kabupaten Soppeng (34,6\%) dan Kabupaten Sidrap (10,7\%). Pada saat hujan terusmenerus turun, kawasan danau tempe beserta wilayah yang terbanjiri mencapai 47.800 ha dan pada musim kering luasannya akan hanya 3.000 ha (Bappeda Kab. Wajo, 2006).

Air yang masuk ke danau tempe berasal dari banyak aliran sungai dua diantaranya adalah Sungai Bila dan Sungai Walanae. Curah hujan pada DAS tersebut juga sangat mempengaruhi kondisi danau tempe. Curah hujan pada masing-masing DAS terdapat sedikit perbedaan baik dari tingkat intensitas maupun waktunya. Berdasarkan pengamatan dari Stasiun Tanru Teddong yang di publikasikan dalam analisis dampak lingkungan hidup pembangunan Bendung Gerak Tempe di Kabupaten Wajo tahun 2007, curah hujan di Das Bila berkisar antara 2000 $\mathrm{mm}$ - $3000 \mathrm{~mm}$ dengan musim hujan berlangsung antara bulan Maret sampai dengan Agustus. Pada DAS Walanae curah hujan rata-rata sebesar $1.500 \mathrm{~mm}$ pada bagian utara, $2.000 \mathrm{~mm}$ pada bagian tengah dan $2.500 \mathrm{~mm}$ pada daerah pegunungan di 
bagian selatan. Sungai yang mengalirkan air dari danau tempe ke laut adalah Sungai Cenranae. Curah hujan pada didaerah ini juga mempengaruhi kondisi di danau tempe, karena air di hilir menjadi tinggi sehingga menghambat keluarnya air dari danau tempe. Rata-rata curah hujan di DAS Cenranae adalah $1.500 \mathrm{~mm}$ pada bagian hulu dan 2.000 $\mathrm{mm}$ pada bagian hilir.

Beberapa permasalahan yang terkait dengan ekosistem Danau Tempe menurut Koeshendrajana et al (2007) antara lain ialah pertama terbatasnya volume air di danau pada musim kemarau, yang menyebabkan kematian dari sebagian binatang, ikan dan tanaman dan dibutuhkannya hal-hal lain untuk bertahan hidup di wilayah yang sangat terbatas tersebut. Kedua kualitas air danau yang jelek karena pembusukan dari material organik mengurangi jumlah oksigen terlarut sehingga membahayakan kehidupan bagian bawah danau yang bisa menyebabkan kematian ikan dan binatang lainnya. Ketiga berkurangnya pepohonan dan tanaman lainnya pada tepian danau, yang pada kondisi normal menjadi habitat bagi kehidupan air. Keempat berkurangnya areal untuk berkembang biak dan bertenggernya burungburung yang biasanya disediakan oleh pepohonan di tepian danau.

\section{Jenis dan Karakteristik Pemanfaatan Sumberdaya di Danau Tempe}

Danau tempe memiliki jenis pemanfaatan sumberdaya yang cukup beragam dan lintas sektoral yaitu sektor perikanan, pertanian, pariwisata dan jasa transportasi. Oleh karena itu, pemanfaatan sumberdaya pada kawasan ini menjadi perhatian beberapa instansi teknis terkait, khususnya ditingkat kabupaten. Masyarakat sendiri sudah sejak lama memanfaatkan keberadaan sumberdaya untuk berbagai kepentingan antara lain seperti untuk memenuhi kebutuhan pangan dan sumber penghasilan keluarga. Jenis pemanfaatan yang berkembang adalah penangkapan sumberdaya perikanan, pemanfaatan lahan untuk kegiatan pertanian dan kegiatan transportasi air. Kegiatan penangkapan sumberdaya perikanan dan kegiatan pertanian dilakukan secara bergantian. Ketika air naik dan menggenangi seluruh kawasan danau, hampir seluruh masyarakat mengalihkan aktivitasnya menjadi nelayan. Pada saat air surut, lahan yang semula terendam air ditanami oleh berbagai jenis tanaman seperti jagung, kacang hijau, kacang kedelai dan semangka. Secara lengkap pola pemanfaatan Sumberdaya Perairan Danau Tempe dapat dilihat pada tabel 1.

Tabel 1. Pola Pemanfaatan Sumberdaya Perairan Danau Tempe, 2007

Table 1. Utilization Pattern of the Tempe Lake Resource, 2007

\section{Fluktuasi airl Water Fluctuation}

Tingkat pemanfaatan/ Level of Utilization

$\begin{array}{ccc}\text { Pertanian/ } & \text { Perikanan/ } & \text { Transportasi/ } \\ \text { Agriculture } & \text { Fisheries } & \text { Transportatio }\end{array}$

Air rendah/ Low Water Surface

Air tinggi/ High Water Surface

Transisi permukaan air rendah ke tinggi/

Transition from low to high water surface

Transisi permukaan air ting gi ke rendah/

Transisiton from high to low water surface

Keterangan/ Explanation:

+ Rendah/Low

++ Sedang/Middle

+++ Tinggi/High 
Berdasarkan jenis pemanfaatannya, wilayah danau tempe dapat dibagi atas beberapa zonasi yaitu zona konservasi, zona perikanan umum, zona ex-ornamen sungai, zona ex-ornamen palawang, zona bungka toddo, zona kantong air produktif (kappro), zona rawa, zona pertanian, zona pariwisata serta zona lalu lintas dan transportasi (Anonim, 2006). Sebutan ex-ornamen ditujukan untuk wilayah yang dibuat secara sengaja dan dikuasai oleh pemerintah sebagai tempat mencari dan menangkap ikan. Selain itu juga terdapat zona ornamen yang merupakan wilayah yang sengaja dibuat untuk mencari ikan oleh para pendahulu dan diwariskan kepada generasi saat ini. Pembuatan zona baru oleh masyarakat sebagai tempat mencari ikan saat ini sudah tidak diperbolehkan. Secara lebih jelas mengenai pengertian pembagian wilayah pada kawasan Danau Tempe di sajikan pada Tabel 2.

\section{a. Karakteristik Pemanfatan Sumberdaya Perikanan}

Pemanfaatan sumberdaya perikanan di danau tempe masih terfokus pada penangkapan sumberdaya ikan.

\section{Tabel 2. Pembagian Wilayah Pada Kawasan Danau Tempe} Table 2. Zoning of the Tempe Lake Resource

\begin{tabular}{|c|c|c|}
\hline No & Wilayah/Area & Pengertian/Description \\
\hline 1. & $\begin{array}{l}\text { Perairan } \\
\text { umum/ Inland } \\
\text { Waters }\end{array}$ & $\begin{array}{l}\text { Semua tempat penangkapan ikan di daerah seperti : Danau, Rawa, } \\
\text { Sungai, Waduk, serta genangan air lainnya IAll fishing ground of } \\
\text { area : Lake, Floodplain, River and other flooded area }\end{array}$ \\
\hline 2. & $\begin{array}{l}\text { Sungai atau } \\
\text { Salo-salo }\end{array}$ & $\begin{array}{l}\text { Perairan sebagai tempat pemasukan dan pengeluaran air di danau } \\
\text { juga merupakan tempat penangkapan ikan IInlet and outlet areas } \\
\text { which are considered the fishing ground }\end{array}$ \\
\hline 3. & Palawang & $\begin{array}{l}\text { Tempat tertentu pada pinggir danau yang batasnya telah ditentukan } \\
\text { untuk dikuasai dengan dipasangi pagar (belat) untuk menjaga } \\
\text { wilayah tersebut/Particular area of lake border which is under control } \\
\text { by someone and use a fence to protect the area }\end{array}$ \\
\hline 4. & $\begin{array}{l}\text { Tanah Telleng/ } \\
\text { Tana Koti }\end{array}$ & $\begin{array}{l}\text { Daerah danau/p inggiran danau yang pada m usim penghujan (air } \\
\text { naik) tetap digenangi air sedang pada musim kemarau kering dan } \\
\text { tanahnya ditanami dengan palawija (disebut juga tanah mati atau } \\
\text { tanah tonrong)/Flooded area which is deluge when rainy season and } \\
\text { no water when dry season that can plant with crops planted }\end{array}$ \\
\hline 5. & Balete & $\begin{array}{l}\text { Tempat yang di buat untuk membantu penangkapan ikan dipinggir } \\
\text { danau yang berbentuk seperti kolam yang bertanggul / Manmade } \\
\text { area near border lake to case capturing fish and have a shape } \\
\text { similar to pond }\end{array}$ \\
\hline 6. & $\begin{array}{l}\text { Reservat/ } \\
\text { Patok Belanda/ } \\
\text { Konservasi }\end{array}$ & $\begin{array}{l}\text { Tempat tertentu dikawasan danau dimana dilarang meng adakan } \\
\text { pemasangan alat tangkap atau mengadakan kegiatan peangkapan } \\
\text { dengan maksud menjaga kelestarian sumberdaya perikanan/A } \\
\text { specific lake area of which is forbidden to have any fishing activity to } \\
\text { ensure resource sustainability }\end{array}$ \\
\hline 7. & Lebba & $\begin{array}{l}\text { Sungai kecil/ saluran kecil yang terdapat dikawasan danau yang } \\
\text { bebas untuk mempercepat keluarnya air dan se bagai tempat lalu } \\
\text { lintas perahu/ Little canal } i \text { the lake area to accelerate outgoing } \\
\text { water and consider a transport hic }\end{array}$ \\
\hline
\end{tabular}


Penangkapan sumberdaya ikan telah dilakukan hampir pada seluruh kawasan perairan baik pada danau, sungai dan rawa.. Pada masing-masing wilayah tersebut, kegiatan penangkapan ikan memiliki perbedaan dari pola dan sifat penggunaan alat tangkap. Perbedaan tersebut diakibatkan adanya karakteristik fisik yang khas pada masing-masing wilayah.

Pada wilayah danau kegiatan penangkapan terdiri dari kegiatan penangkapan ikan secara umum dan penangkapan ikan pada daerah yang dikuasai oleh seorang atau sekelompok masyarakat tertentu. Penangkapan ikan secara umum adalah kegiatan penangkapan yang dilakukan pada daerah umum, akses terbuka untuk masyarakat umum, dengan menggunakan alat tangkap lanra (jaring insang tetap), ja'bah dan konde. Jaring insang tetap yang digunakan memiliki mata jaring dengan ratarata berukuran $5 \mathrm{~cm}$.menurut ketentuan yang berlaku panjang jaring yang diperbolehkan untuk satu orang nelayan adalah 500 meter. Jenis ikan yang tertangkap dengan menggunakan alat tangkap tersebut cukup beragam antara lain ikan mas, sepat, dan mujair. Ja'bah adalah sejenis perangkap yang terbuat dari kawat dan diletakkan pada dasar danau. Jenis ikan utama yang tertangkap dengan menggunakan alat tangkap ini adalah jenis ikan dasar seperti mujair, gabus, dan kandiya. Meskipun demikian, tidak ada pengkhususan jenis ikan tangkapan dari pengunaan alat tangkap ja'bah. Konde (fishpots) merupakan alat tangkap yang terbuat dari bambu yang disusun sedemikian rupa, sehingga mengarahkan ikan pada 2 buah kantong perangkap yang terletak pada sisi sebelah kiri dan kanan. Berdasarkan peraturan yang berlaku panjang konde tidak boleh melebihi 50 meter dan jarak antar satu konde dengan konde lainnya adalah 100 meter. Waktu pemasangan konde telah diatur dalam perda kab wajo tahun 2.000 yaitu mulai tangal 1 April sampai dengan 31 Desember.

Penangkapan ikan pada daerah yang dikuasai oleh seorang atau sekelompok masyarakat tertentu terdiri dari penangkapan pada daerah palawang dan kegiatan penangkapan pada daerah tengah danau dengan menggunakan teknik bungka toddo. Palawang adalah tempat tertentu pada pinggir danau yang batasnya telah ditentukan untuk dikuasai dengan dipasangi belat di sekelilingnya. Batas-batas palawang ditandai secara jelas dan mulai efektif berlaku ketika air sudah mulai surut sehingga terlihat batas belat yang memiliki ketinggian $1,5 \mathrm{~cm}$ dari dasar danau. Pada saat air berada ketinggian $30 \mathrm{~cm}$ dari tinggi belat, nelayan umum masih dapat melintas dengan bebas dan melakukan kegiatan penangkapan ikan. Waktu pemasangan belat pada palawang berbedabeda pada masing-masing kecamatan terantung pada ketinggian air pada masingmasing daerah.

Bungka Toddo merupakan upaya penangkapan ikan dengan membentuk suatu areal tertentu pada wilayah danau. Batas areal menggunakan patok bambu sebagai tiang dan belat (alat yang terbuat dari anyaman bambu) sebagai pembatas wilayah. Pada bagian tengah diisi dengan berbagai tanaman air untuk menarik ikan masuk kedalam areal bungka toddo. Panen atau penangkapan ikan dilakukan ketika air sudah mulai surut. Surutnya air menyebabkan ikan-ikan terperangkap, sehingga sangat mudah untuk ditangkap. Setiap satu bungka toddo terdiri dari satu kelompok yang beranggotakan antara 5-6 orang. Didalam satu kelompok umumnya terdapat satu orang sebagai pemodal, namun juga terdapat yang modalnya merupakan kontibusi dari setiap anggota kelompok. Ukuran satu bungka toddo menurut aturan yang berlaku adalah 125 x 125 meter atau memiliki keliling maksimal 500 meter. Selain itu jarak antara satu bungka toddo dengan bungka toddo yang lainnya sekurangkurangnya adalah 200 meter. Praktik yang terjadi dilapangan, banyak bungka toddo yang memiliki ukuran lebih besar dan jarak yang lebih rendah dari yang telah ditentukan. 
Jenis aktivitas yang menyebabkan semakin turunnya sumberdaya perikanan menurut masyarakat adalah intensifnya penggunaan bungka toddo dan ja'bah sebagai alat penangkapan ikan. Perkembangan bungka toddo saat ini memang marak dilakukan dan semakin sulit dikendalikan. Perda No. 5 Kabupaten Wajo tahun 2.000 yang mengatur tentang bungka toddo tidak dapat berjalan secara efektif, karena lemahnya pengawasan dan penegakan aturan. Ukuran bungka toddo yang ada, banyak ditemukan dengan ukurannya jauh lebih besar dari aturan yang diperbolehkan. Selain itu, masih banyak juga pelanggaran mengenai aturan jarak antar bungka toddo. Jarak yang diperbolehkan sekurangkurangnya adalah 150 meter, kenyataan yang ada banyak yang berjarak dibawah 50 meter. Hal-hal tersebut diatas dinilai memberikan kontribusi yang cukup besar atas terjadinya sedimentasi di danau tempe. Berdasarkan penelitian Tjahjo dan Wardoyo (1995), bungka toddo juga mengakibatkan benih-benih ikan turut tertangkap. Akibatnya kualitas sumberdaya perairan dan perikanan semakin menurun. Ja'bah juga dinilai memberikan dampak terhadap penurunan sumberdaya perikanan didanau tempe. Ja'bah umumnya diletakkan pada dasar danau, terutama wilayah yang diduga sebagai tempat berlindung atau mencari makan ikan seperti dibawah tanaman air atau akar-akar pohon. Hal ini diduga oleh para nelayan turut menganggu atau menghambat ikan-ikan yang akan memijah pada daerah tersebut.

Faktor alam memiliki yang memiliki pengaruh terhadap kualitas sumberdaya perairan dan perikanan setempat adalah sedimentasi yang berasal dari aliran air sungai yang masuk ke danau tempe. Aliran air sungai banyak membawa material terutama tanahtanah yang tererosi pada daerah hulu. Sungai utama yang memberikan dampak sedimentasi paling besar didanau tempe adalah Sungai Walannae dan Sungai Bila. Jumlah total material yang terendap didanau tempe setiap tahunnya mencapai $518.609 \mathrm{~m}^{3} /$ tahun (Nippon Koei, 1977 dalam Bappeda Kab Wajo, 2006).

Upaya pemerintah untuk menjaga kelestarian danau tempe, sehingga sumberdaya perikanan terus dapat dimanfaatkan adalah dengan mempertahankan daerah reservat dan melakukan penebaran bibit. Reservat pada wilayah danau tempe lebih dikenal sebagai patok belanda. Nama patok belanda berasal dari sebutan masyarakat atas batas-batas daerah larangan menangkap ikan yang dipasang pada saat pemerintahan belanda. Wilayah ini merupakan daerah terdalam dan tidak pernah kering sepanjang tahun. Luas wilayah patok belanda semenjak dari ditetapkannya sampai dengan saat ini adalah 250 ha. Tujuannya adalah agar terdapat wilayah untuk memulihkan sumberdaya ikan yang telah terkuras karena terus-menerus ditangkap oleh masyarakat. Penebaran bibit dilakukan setiap tahun ketika air didanau tempe sudah mulai menggenangi sebagian besar wilayah. Penebaran bibit bertujuan untuk menjamin ketersediaan stok ikan, sehingga hasil tangkapan ikan meningkat pada saat akhir musim penangkapan.

\section{b. Karakteristik Pemanfaatan Sumberdaya Pertanian}

Pemanfaatan sumberdaya pertanian dilakukan ketika air surut dan berganti dengan daratan yang berbentuk lereng. Pada Kabupaten Wajo wilayah ini disebut sebagai tanah koti atau zona pertanian, yang terdiri dari beberapa bagian berdasarkan jarak dengan daratan pada saat batas air tertinggi dengan daerah danau yang tidak kering pada saat musim kemarau yang disebut langga. Langga satu adalah daerah yang paling dekat dengan dataran pada saat air tertinggi dan merupakan daerah yang mengalami kering paling awal, sedangkan langga yang paling dekat dengan batas tinggi danau terendah yang mengalami kering paling akhir adalah langga empat. Kondisi tersebut dipengaruhi oleh ketinggian 
suatu tempat. Semakin tinggi suatu tempat, maka lahan akan semakin cepat mengalami kering. Hal tersebut berarti pula, semakin intensif pemanfaatan lahan untuk kegiatan pertanian. Proporsi wilayah berdasarkan tingkat ketinggiannya disajikan pada Tabel 3.

Wilayah pasang surut disekitar danau tempe didominasi oleh wilayah yang landai dengan tingkat kemiringan $0-2 \%$ (Tabel 4.). Kondisi tersebut menjadikan lahan yang ada sesuai untuk berbagai jenis tanaman. Terdapat tiga kelompok besar tanaman yang diusahakan yaitu tanaman palawija, padi, dan hortikultura. Tanaman palawija yang banyak di usahakan adalah jagung, ubi kayu, kacang kedelai dan kacang hijau, sedangkan hortikultura yang banyak ditanam adalah tomat dan semangka.

Wilayah pasang surut yang dijadikan lahan pertanian, dibagi bersama antar masyarakat yang tinggal disekitarnya. Menurut aturan yang berlaku, pembagian lahan pertanian dilakukan dengan cara mengundi. Hal tersebut dimaksudkan agar setiap masyarakat mendapat kesempatan yang sama untuk menguasai lahan yang dinilai strategis untuk melakukan kegiatan pertanian.

Tabel 3. Ketinggian lahan di wilayah pasang surut Danau Tempe, Kabupaten Wajo Table 3. Land altitude in the Tempe Lake flood area, District Wajo

\begin{tabular}{rlrrr}
\hline No & $\begin{array}{c}\text { Kecamatan/ } \\
\text { County }\end{array}$ & Ketinggian/ Altitude & Luas/Width (Ha) & $\begin{array}{r}\text { Persentase/ } \\
\text { Percentage (\%) }\end{array}$ \\
\hline 1 & Sabbangparu & $100-500 \mathrm{~m}$ & 14,75 & 0,12 \\
& & $25-100 \mathrm{~m}$ & $2.616,66$ & 21,06 \\
\multirow{2}{*}{2} & & $7-25 \mathrm{~m}$ & $8.759,39$ & 70,51 \\
& & $100-500 \mathrm{~m}$ & 4,20 & 0,10 \\
& & $25-100 \mathrm{~m}$ & $1.656,60$ & 38,82 \\
3 & \multirow{2}{*}{ Tempe } & $7-25 \mathrm{~m}$ & $1.646,15$ & 38,58 \\
& & $100-500 \mathrm{~m}$ & 343,06 & 2,26 \\
& & $25-100 \mathrm{~m}$ & $10.414,03$ & 68,46 \\
4 & & $7-25 \mathrm{~m}$ & $2.598,88$ & 17,08 \\
& & $25-100 \mathrm{~m}$ & $1.465,83$ & 9,04 \\
& & $7-25 \mathrm{~m}$ & $10.857,81$ & 66,98 \\
\hline
\end{tabular}

Sumber/Source : Putra dan Sadat, 2007

Tabel 4. Kemiringan lahan di sekitar Danau Tempe

Table 4. Land slope around the Tempe Lake

\begin{tabular}{llrrr}
\hline No & Kecamatan/ County & Kemiringan/ Slope & Luas/ Width (Ha) & $\begin{array}{c}\text { Persentase/ } \\
\text { Percentage (\%) }\end{array}$ \\
\hline 1. & Sabbangparu & $0-2 \%$ & $9.677,68$ & 77,91 \\
& & $2-5 \%$ & $1.418,98$ & 11,42 \\
2 & Tempe & $15-40 \%$ & 293,99 & 2,37 \\
& & $0-2 \%$ & $2.266,5$ & 53,11 \\
& & $2-5 \%$ & 901,38 & 21,12 \\
3 & Tanasitolo & $15-40 \%$ & 139,07 & 3,26 \\
& & $0-2 \%$ & $8.242,47$ & 54,18 \\
& & $2-5 \%$ & $4.466,21$ & 29,36 \\
4 & Belawa & $15-40 \%$ & 617,55 & 4,06 \\
\hline
\end{tabular}

Sumber /Source: Putra dan Sadat, 2007 


\section{c. Karakteristik Pemanfatan Sumberdaya Sebagai Prasarana Transportasi}

Salah satu pemanfaatan sumberdaya di komplek danau tempe adalah menggunakan badan perairan sebagai pra sarana transportasi umum masyarakat. Kegiatan ini dapat dilakukan sepanjang tahun, tetapi umumnya hanya akan berjalan pada saat air mulai membanjiri kompleks danau tempe. Ketika air membanjiri sebagian besar komplek danau tempe, banyak jalan-jalan darat yang aksesnya tertutup. Perjalanan darat yang masih dapat dilalui harus ditempuh dengan cara memutar, sehingga jarak dan waktu tempuh semakin lama. Hal tersebut membuat masyarakat lebih cenderung memilih transportasi air daripada transportasi darat. Sebaliknya pada saat musim kering, masyarakat cenderung lebih memilih jalan darat dari pada jalan air. Sehingga para pelaku usaha transportasi air memilih tidak beroperasi, karena bersaing dengan sarana transportasi darat yang lebih mudah dalam mengakses lokasi tujuan dan dapat sampai dengan lebih cepat. Pada bulan 7 sampai dengan bulan 8 , merupakan musim ramai penumpang seiring dengan kalender wisata tahunan pada komplek danau tempe. Para wisatawan menggunakan sarana transportasi air untuk mengamati migrasi burung-burung dan melihat rumah terapung yang menjadi ciri khas masyarakat komplek danau tempe. Selain itu para wisatawan juga menggunakan perahu untuk melihat lomba-lomba pada perayaan hari kemerdekaan seperti lomba perahu dayung.

Kegiatan usaha transportasi air memiliki aturan yang tidak tertulis yang disepakati oleh setiap pelaku usaha ini. Transportasi air memiliki pangkalan layaknya sebuah terminal. Masyarakat yang hendak menggunakan alat transportasi ini naik dan turun pada tempat yang telah ditentukan. Operasional usaha pada pangkalan menggunakan sistem antrian, sehingga terlihat cukup tertib. Setiap perahu yang akan mengangkut penumpang, tidak boleh mendahului perahu yang telah sampai lebih dulu.

\section{Nilai Ekonomi Pemanfaatan Sumberdaya Danau tempe}

Pemanfaatan yang dilakukan oleh masyarakat telah memberi nilai ekonomi khususnya bagi yang masyarakat yang terlibat baik langsung atau tidak langsung dari mata rantai kegiatan usaha pemanfaatan sumberdaya di danau tempe. Nilai ekonomi pemanfaatan sumberdaya berdasarkan jenis pemanfaatan sumberdaya dapat dibagi menjadi sebagai berikut :

\section{a. Nilai Ekonomi Pemanfaatan Sumberdaya Perikanan}

Kegiatan penangkapan perikanan telah lama berkembang pada komplek Danau Tempe. Bahkan produksi perikanan dari kawasan danau pernah mencapai 50.000 ton per tahun pada tahun 1950-an. Namun akibat terjadinya perubahan kondisi baik secara alami maupun aktivitas manusia, produktivitas danau tempe saat ini terus mengalami penurunan. Pada kurun waktu 2001 sampai dengan 2005 saja terjadi penurunan produksi dengan rata-rata penurunan pertahun sebesar $6,45 \%$. Produksi hasil perikanan perairan umum daratan pada tiga Kabupaten yang berbatasan langsung dengan danau tempe pada tahun 2005 tercatat sebesar 12.526,7 ton. Kabupaten wajo memberikan kontribusi paling besar yaitu $69,9 \%$ atau sebesar $8.756,1$ ton. Gambaran umum dari kondisi pemanfaatan dan perkembangannya disajikan dalam Tabel 5.

Nilai ekonomi pemanfaatan sumberdaya perikanan sangat dipengaruhi oleh besarnyaekstrasi atau penangkapan yang dilakukan oleh masyarakat. Berdasarkan hasil survey, diketahui bahwa rata-rata responden memiliki nilai produksi sebesar $4.597 \mathrm{Kg} / \mathrm{tahun}$ dengan rata-rata harga ikan adalah $\mathrm{Rp}$. $5.368 / \mathrm{kg}$. Jenis ikan yang dominan tertangkap adalah Tawes (Puntius sp) yaitu sebesar 


\section{Tabel 5. Produksi dan Nilai Produksi Hasil Perikanan Kawasan Danau Tempe Tahun 2001-2005}

Table 5. Production and Production Value of Fisheris at the Tempe Lake, 2001-2005

\begin{tabular}{llccl}
\hline No & $\begin{array}{c}\text { Tahun/ } \\
\text { Years }\end{array}$ & $\begin{array}{c}\text { Produksi/ } \\
\text { Production } \\
\text { (ton) }\end{array}$ & $\begin{array}{c}\text { Nilai Produksi/ } \\
\text { Production Value } \\
\text { (Rp.000) }\end{array}$ & Keterangan/ Description \\
\hline 1 & 2001 & $13.386,1$ & 61.748 .526 & Meliputi Kecamatan \\
2 & 2002 & $10.068,9$ & 50.818 .200 & Sabbangparu, Tempe, \\
3 & 2003 & $10.843,9$ & 75.915 .950 & Tanasitolo, dan Belawa \\
4 & 2004 & $8.756,1$ & 88.621 .758 & \\
5 & 2005 & $9.785,5$ & 89.119 .100 & \\
\hline
\end{tabular}

Sumber/Source : BPS di olah/ BPS processed, 2006

(35,7\%) kemudian Sepat(Trichogaster tricopterus) (18,9\%), Mujair (Oreochromis mossambicus) $(13,6 \%)$, Gabus (Ophiocephalus pleurothalmus) (10,96\%), Betok (Anabas tetudineus) (10\%), Mas (Cyprinus Carpio) (6,3\%), Nila (Oreochromis niloticus) $(3,9 \%)$ dan lain-lain $(0,5 \%)$, dapat dilihat dari tabel 6.

Untuk mengukur nilai ekonomi sumberdaya, diperlukan estimasi terhadap fungsi permintaan terhadap sumberdaya. Hasil dari pengolahan data, diketahui bahwa permintaan terhadap sumberdaya perikanan tangkap mengikuti fungsi berikut :

$$
\begin{aligned}
& \operatorname{Ln} Q=7.998-1.12 \frac{1}{n} \sum_{i=1}^{n} \operatorname{Ln} X_{1}-0.256 \frac{1}{n} \sum_{i=1}^{n} \operatorname{Ln} X_{2} \\
& +0.078 \frac{1}{n} \sum_{i=1}^{n} \operatorname{Ln} X_{3}+0.044 \frac{1}{n} \sum_{i=1}^{n} \operatorname{Ln} X_{4} \\
& +0.639 \frac{1}{n} \sum_{i=1}^{n} \operatorname{Ln} X_{5}+0.068 \frac{1}{n} \sum_{i=1}^{n} \operatorname{Ln} X_{6}
\end{aligned}
$$

Berdasarkan fungsi tersebut diduga bahwa pendapatan $\left(X_{5}\right)$ merupakan faktor yang paling besar mempengaruhi permintaan terhadap sumberdaya. Pendapatan yang semakin tinggi dari pemanfaatan sumberdaya ikan, membuat keinginan untuk melakukan

Tabel 6. Estimasi jumlah hasil tangkapan ikan Danau Tempe, 2007

Table 6. Estimated fish production in the Tempe Lake, 2007

\begin{tabular}{lll}
\hline No & \multicolumn{1}{c}{ Jenis Ikan/ Species } & $\begin{array}{l}\text { Estimasi Jumlah } \\
\text { Tangkapan (ton/tahun) / Estimated } \\
\text { production }\end{array}$ \\
\hline 1 & Tawes (Puntius sp) & 4494,69 \\
2 & Sepat (Trichogaster tricopterus) & 2375,11 \\
3 & Mujair (Oreochromismossambicus) & 1715,88 \\
4 & Gabus (Ophiocephaluspleurothalmus) & 1377,45 \\
5 & Betok (Anabas tetudineus) & 1257,92 \\
6 & Mas (Cyprinus carpio) & 786,94 \\
7 & Nila (Oreochromis niloticus) & 493,59 \\
8 & Lain-lain (Others) & 71,42 \\
\hline & Total & $12.572,99$ \\
\hline
\end{tabular}

Sumber/Source : Data primer diolah/ primary data processed, 2007 
penangkapan yang lebih besar. Harga $\left(X_{1}\right)$ sumberdaya memiliki hubungan yang negatif terhadap permintaan sumberdaya. Hal ini di sebabkan asumsi yang digunakan pada penelitian ini adalah terjadi pada titik keseimbangan, dimana penawaran sama dengan permintaan (Q). Berdasarkan hukum penawaran, semakin besar jumlah ekspetasi terhadap sumberdaya akan mengakibatkan harga semakin rendah. Faktor usia $\left(X_{2}\right)$ berhubungan secara negatif terhadap permintaan sumberdaya karena produktivitas seseorang akan semakin menurun seiring bertambahnya usia. Usia masyarakat yang menjadi responden pada penelitian ini minimum adalah 20 tahun, maksimum 65 tahun dan rata-rata 41 tahun. Sehingga cukup jelas bahwa secara rata-rata, produktivitas nelayan yang berusia antara 20 - 41 tahun akan lebih besar bila dibandingkan dengan nelayan yang berusia antara 41 - 65 tahun. Tingkat pendidikan $\left(\mathrm{X}_{3}\right)$, jumlah anggota keluarga $\left(X_{4}\right)$ dan pengalaman $\left(X_{6}\right)$ memiliki sedikit pengaruh positif terhadap permintaan. Hal ini memberikan makna bahwa tingkat pendidikan, jumlah anggota keluarga danpengalaman memberikan motivasi yang lebih baik dalam berusaha, meskipun tidak terlalu jelas terlihat dilapangan.

Nilai surplus konsumen dari pemanfaatan sumberdaya perikanan adalah sebesar Rp. 175.476.518/RTP yang mencerminkan nilai ekonomi dari sumberdaya perikanan. Nilai ekonomi total dari pemanfaatan sumberdaya perikanan didapat dengan mengalikan nilai surplus konsumen dengan total jumlah RTP yang ada di sekitar danau tempe. Hasil yang diperoleh adalah sebesar Rp. $479,928,275,363 /$ tahun dengan tingkat produktivitas Rp. 10.040.340/ ha/ tahun. (Tabel 7).

\section{b. Nilai Manfaat Langsung Sumberdaya Pertanian}

Sumberdaya pertanian memberikan nilai ekonomi yang paling besar dari pemanfaatan sumberdaya diwilayah danau tempe. Hasil dari penghitungan diketahui bahwa nilai ekonomi pemanfaatan sumberdaya pertanian adalah sebesar Rp.1.021.015.603,621. Permintaan terhadap sumberdaya pertanian mengikuti fungsi sebagai berikut:

$$
\begin{aligned}
& \operatorname{Ln} Q=1.107-1.184 \frac{1}{n} \sum_{i=1}^{n} \operatorname{Ln} X_{1}+0.040 \frac{1}{n} \sum_{i=1}^{n} \operatorname{Ln} X_{2} \\
& +0.049 \frac{1}{n} \sum_{i=1}^{n} \operatorname{Ln} X_{3}+0.103 \frac{1}{n} \sum_{i=1}^{n} \operatorname{Ln} X_{4} \\
& +1.009 \frac{1}{n} \sum_{i=1}^{n} \operatorname{Ln} X_{5}+0.014 \frac{1}{n} \sum_{i=1}^{n} \operatorname{Ln} X_{6}
\end{aligned}
$$

Pada fungsi diatas, diketahui bahwa seluruh faktor berpengaruh positif terhadap permintaan sumberdaya pertanian kecuali harga. Seperti pada persamaan permintaan terhadap sumberdya perikanan, persamaan ini juga mengasumsikan bahwa permintaan dan penawaran berada pada titik keseimbangan (equilibirium) dimana permintaan sama dengan penawaran sumberdaya. Oleh sebab itu, harga berbanding terbalik dengan permintaan terhadap sumberdaya. Faktor yang diduga

Tabel 7. Jumlah RTP perikanan di Sekitar Danau Tempe, 2007

Table7. Number of Fisheris Household Around the Tempe Lake, 2007

\begin{tabular}{clc}
\hline No & Kabupaten/ Distric & Jumlah RTP/ Number of Household \\
\hline 1. & Wajo & 1.507 \\
2. & Sidrap & 501 \\
3. & Soppeng & 727 \\
\hline & Total & 2.735
\end{tabular}


paling besar mempengaruhi permintaan adalah pendapatan $\left(X_{5}\right)$. Semakin besar pendapatan, akan mendorong masyarakat untuk melakukan pemanfaatan yang lebih besar. Kondisi yang serupa juga terlihat padafaktor-faktor yang lainnya. Bertambahnya usia $\left(\mathrm{X}_{2}\right)$, tingginya tingkat pendidikan $\left(\mathrm{X}_{3}\right)$, Besarnya jumlah anggota keluarga $\left(X_{4}\right)$, dan pengalaman $\left(X_{6}\right)$ akan membuat seseorang termotivasi untuk melakukan usaha yang mendorong tingginya permintaan terhadap sumberdaya.

Produktivitas lahan untuk kegiatan pertanian adalah sebesar Rp. 75.716.130/Ha/Thn yang dihitung .berdasarkan surplus konsumen. Luas daerah yang dipengaruhi air dari danau tempe dan digunakan sebagai lahan pertanian saat ini mencapai 14.622 ha dengan wilayah terbesar berada pada Kabupaten Wajo yaitu $7.924 \mathrm{Ha}$ (54\%). Sisanya terbagi pada Kabupaten Sidrap $3.451 \mathrm{Ha}(23,6 \%)$ dan Kabupaten Soppeng $3.247 \mathrm{Ha}(22,2 \%)$ dapat dilihat di tabel 8 .

\section{c. Nilai Manfaat Langsung Transportasi}

Selain sektor pertanian dan perikanan yang merupakan sektor utama, terdapat sektor transportasi yang memberikan nilai manfaat secara langsung kepada sebagian masyarakat. Sebagian masyarakat memanfaatkan sungai sebagai jalur transportasi umum khususnya ketika air didanau tempe mulai menggenangi sebagian besar wilayah yang sebelumnya dapat dilalui transportasi darat. Jumlah masyarakat yang tercatat sebagai pemanfaat disektor ini adalah sebanyak 229 orang. Berdasarkan penghitungan dengan menggunakan discount factor $11 \%$ dan tahun proyeksi selama 5 tahun diketahui bahwa nilai manfaat langsung transportasi bagi masyarakat adalah sebesar Rp. 2.551.776.657 atau Rp. 425.296.110/ tahun.

\section{d. Total Nilai Manfaat Langsung}

Secara keseluruhan, nilai manfaat langsung sumberdaya ekosistem danau tempe memberikan pengaruh yang besar terhadap ekonomi masyarakat. Nilai total manfaat langsung adalah sebesar Rp.1.501.369.175.094 / tahun (Tabel 9).

Jenis pemanfaatan yang memberikan kontribusi terbesar adalah sektor pertanian yang memberikan nilai manfaat lebih dari $68 \%$ dari nilai total manfaat sumberdaya. Kondisi ini memberikan arti bahwa pertanian merupakan sumber penghasilan utama bagi sebagian masyarakat yang menggantungkan yang menggantungkan kehidupan ekonominya dari sumberdaya di danau tempe. Perikanan meskipun tidak memberikan nilai yang paling besar, tetapi memberikan peranan yang penting sebagai sumber pendapatan dan pemenuhan kebutuhan gizi masyarakat.

Tabel 8. Luas Lahan Pertanian Pasang Surut di Danau Tempe berdasarkan Kabupaten

Table 8. Agriculture land in floodplain area at the Tempe Lake by Distric

\begin{tabular}{ccccr}
\hline No. Kabupaten/ Distric & $\begin{array}{c}\text { Luas/ Width } \\
\text { (Ha) }\end{array}$ & $\begin{array}{c}\text { Produktivitas } \\
\text { (Rp/Ha/Thn)/ } \\
\text { Productivity } \\
\text { (Rp/Ha/Years) }\end{array}$ & $\begin{array}{c}\text { Nilai Ekonomi/ } \\
\text { Economic Values }\end{array}$ \\
\hline 1. & Sidrap & 3.451 & 75.716 .130 & 261.296 .364 .630 \\
2. & Soppeng & 3.247 & 75.716 .130 & 245.850 .274 .110 \\
3. & Wajo & 7.924 & 75.716 .130 & 599.974 .614 .120 \\
\hline & Total & $\mathbf{1 4 . 6 2 2}$ & & $\mathbf{1 . 0 2 1 . 0 1 5 . 6 0 3 . 6 2 1}$ \\
\hline
\end{tabular}

Sumber : Interpretasi Citra Landsat, 2007/Source : Landsat Interpretation, 2007 
Tabel 9. Nilai Manfaat Langsung Ekosistem Danau Tempe, 2007

Tabel 9. Direct Benefit Value of the Tempe Lake Ecosystem, 2007

\begin{tabular}{lcc}
\hline \multicolumn{1}{c}{ Jenis Nilai/Kind of Value } & $\begin{array}{c}\text { Nilai (Rp. Per Tahun)/ } \\
\text { Value (Rp/Year) }\end{array}$ & $\begin{array}{c}\text { Produktivitas (Rp/Tahun/Ha)/ } \\
\text { Productivity (Rp/Year/Ha) }\end{array}$ \\
\hline Perikanan Tangkap / CatchFiseries & 479.928 .275 .363 & 10.040 .340 \\
Pertanian / Agriculture & 1.021 .015 .603 .621 & 69.827 .356 \\
Transportasi / Transportation & 425.296 .110 & \\
\hline Total & 1.501 .369 .175 .094 &
\end{tabular}

Sumber : Data Primer di Olah, 2007/Source

: Primary Data Processed, 2007

\section{KESIMPULAN DAN IMPLIKASI KEBIJAKAN}

Karakteristik sumberdaya perairan pada Komplek Danau Tempe yang khas memberikan pengaruh yang besar terhadap karakteristik pemanfaatan sumberdaya di komplek Danau Tempe. Pemanfaatan sumberdaya untuk kegiatan perikanan banyak dilakukan pada saat air sedang pasang dan membanjiri komplek Danau Tempe. Selain itu, sarana transportasi air menjadi alat transportasi utama yang digunakan oleh masyarakat pada saat tersebut. Sehingga usaha jasa transportasi air banyak dilakukan. Sebaliknya, kegiatan pertanian akan marak pada saat air mulai surut.

Kegitan perikanan yang berkembang adalah kegiatan perikanan tangkap. Kegiatan perikanan budidaya sampai dengan saat ini belum dilakukan karena dinilai tidak sesuai dengan kondisi perairan. Penangkapan ikan yang dilakukan diantaranya memanfaatkan kondisi pasang surut air dalam metode penangkapannya seperti bungka toddo, palawang dan ballete. Umumnya metode penangkapan ini dilakukan oleh nelayannelayan yang memiliki modal cukup besar. Sedangkan nelayan-nelayan kecil melakukan penangkapan ikan dengan menggunakan alat tangkap yang digunakan sepanjang air masih sepanjang air tergenang seperti jaring insang tetap dan ja'bah.
Nilai ekonomi komplek Danau Tempe dari pemanfaatan yang dilakukan menunjukkan nilai yang cukup besar mencapai Rp.1.489.149.383.605 Nilai ekonomi penangkapan ikan adalah Rp. $479,928,275,363$ per tahun, sedangkan untuk kegiatan pertanian mencapai Rp. $1,021,015,603,621$ per tahun dan kegiatan transportasi umum masyarakat sebesar. Rp. $425,296,110$. Nilai tersebut mengindikasikan bahwa, sumberdaya perairan komplek danau tempe memberi kontribusi ekonomi yang cukup besar baik bagi masyarakat maupun pemerintah. Namun demikian perlu dilakukan pengelolaan yang lebih baik pada masa-masa mendatang mengingat semakin berkurangnya hasil sumberdaya danau tempe khususnya perikanan. Bila kondisi demikian tidak mendapat perhatian yang serius, maka diperkirakan nilai ekonomi dari pemanfaatan sumberdaya di danau tempe akan semakin berkurang.

\section{DAFTAR PUSTAKA}

Anonimous.2006. Draft Materi Kongres TaniNelayan (KONTAN) Danau Tempe. Kompleks Rumah Aadat Atakkae Sengkang. Sulawesi Selatan

Anonimous.2000. Perda Kabupaten Wajo

No.5.tahun 2000. Retribusi Pemakaian

Kekayaan Daerah. Sulawesi Selatan

Adrianto, L. 2006. Sinopsis Pengenalan 
Konsep dan Metodologi Valuasi Ekonomi Sumberdaya Pesisir dan Laut. PKSPLIPB. Bogor

Bappeda Kabupaten Wajo.2006. Pengelolaan Kawasan Danau Tempe Melalui Pendekatan Pembangunan Berkelanjutan yang Berwawasan Lingkungan (makalah). Sulawesi selatan

Dosi C, 2000. Environmental Values, Valuation Methods, and Natural Disaster Damage Assessment. Santiago de Chile

Putra, Nana S. Udi dan Sadat, 2007.
Identifikasi Kawasan Danau Tempe Provinsi Sulawesi Selatan. Balai Budidaya Air Payau Takalar. Direktorat Jenderal Perikanan Budidaya. Departemen Kelautan dan Perikanan. Sulawesi Selatan

Koeshendrajana, S., et al. 2007. Riset Identifikasi, Karakterisasi, dan Valuasi Sosial Ekonomi Sumberdaya Perairan Umum Daratan. Laporan Teknis Kegiatan Penelitian. Balai Besar Riset Kelautan dan Perikanan. BRKP. Jakarta. 